\title{
東京都芝白金、旧海軍墓地に埋葬された 江戶末、明治初年の日本人頭骨*
}

鈴木 尚・佳 倉 朔・林 都志夫

田辺義一・今井義量

I 緒 言

歷史時代に怙ける日本人形質の時代的変化をあとづける試みは、約10年来の鈴木その他に よる鎌倉・室町・江戸の各時代の関東地方より出土した人骨群の研究によつて、頭骨に関し ては、ほぼその輪廓を知り得るに至つたと見ることができる(鈴木 1954、1956、1957；鈴木 他 1956、1957、1958)。その変化は、例光ば短頭化現象の名で知られる頭形の変化などの如 く、多くの形質に括いて鎌倉時代から江戸時代に至る期間ては比較的緩やかに経過し、江戸 時代以降現代に至る間に打いて急激であるように見兄る。

ここに報告する頭骨群は江戸時代と現代との移行期に属するるので、その特徽を明らかに することによつて、これら両時代間の急激な変化の様相を知るための有力な一資料を追加す ることができると信ずるものである。

\section{II 研究枋料ならびに研究方法}

昭和28年末より29年 1 月にかけて、東京都港区芝白金にある旧海軍墓地の改葬に際して、 その埋萑人骨を調查する機会を得た。この白金海軍墓地飞は明治初年以来の初期の海軍軍人 を埋葬してあり、その個数は 592 体に及ぶ。遗体の中には火葬されたものるあつたが、多く

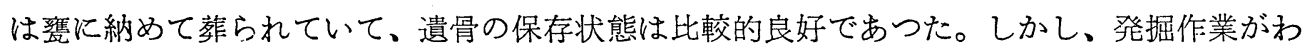
れわれと関係なく、都関係者の監督のもとに人夫の手によつて行われたこと、許された調査 日数が僅かであつたことなどの理由により、その中で調查し得たのは頭骨 191 個のみで、下 靧は大部分避離していた。

墓地の管理者が保存している艮簿には、埋葬者各個人の姓名・生年及び死亡年・階級・身 分・出身地なぞが記されてあるが、上に述べたような発掘状態であつたので、調查した個体 を帳簿と照合することは極く一部のるのを除いては不可能であつた。しかしながら帳簿を通 覧して知り得た埋葬者全体の年齢・身分・出身地など火ついての集団的特性は、調査し得た191 個体の集団ともほぼ同様であると推測し得る。したがつて次に帳簿に記載された埋葬者全体 に関する事項を述べる。

埋葬者は旧海軍軍人であるから性別はすべて男性である。

埋葬者の出身地は次の如く九州地方と中国地方が全体の $64 \%$ を占め、特に鹿児島、山口、 広島などの県が多く、初期の海軍に括ける旧藩勢力の強さをうかがわしめる。

九州地方 計 203

*乙の研究の要旨は昭和 33 年10月に第13回日本人類学会日本民族学協会連合大会において発表された。 


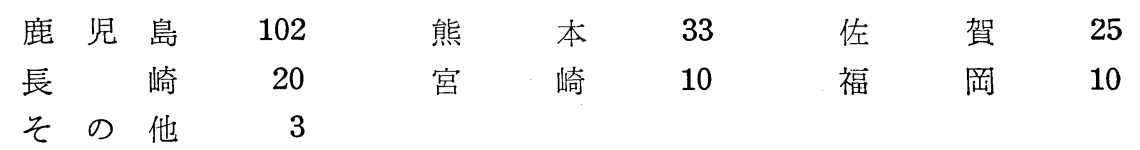

四国地方誴 22

愛媛 11 高知 10 そ

中国地方計 169

山 口 89 広島 64 岡出 12

その他 4

近畿地方計 50

和 歌山 28 兵庫 $10 \quad$ 三 $\begin{array}{lll}\text { 重 } & 10\end{array}$

その他 2

中部地方計 77

石 川 30 新 潟 22 静周 13

その他 12

関東地方計 38

東 京 23 そ

東北地方計 20

その他計 4

総計 583

出身地不明のもの 9

墓地は甲乙丙丁戊己の 6 墓区に分けられてあり、第 1 表の如く各墓区により埋葬者の階級 別の割合を異にし、また士族・平民の身分に属する者の割合も異るが、これは当時の海軍に 於て上級の軍人ほど士族出身者の占める率が高かつた傾向を示すものである。

第 1 表 階級別拈よび身分別の埋葬者数

\begin{tabular}{|c|c|c|c|c|c|c|c|c|}
\hline \multirow{2}{*}{ 墓 } & \multirow{2}{*}{ 区 } & \multicolumn{2}{|r|}{ 階 } & \multicolumn{2}{|l|}{ 級 } & \multicolumn{2}{|c|}{ 身 } & 分 \\
\hline & & 士 官 & 下士官 & 兵 & 計 & 士 族 & 平 民 & 計 \\
\hline \multicolumn{2}{|c|}{ 甲十乙十丙 } & $\begin{array}{c}66 \\
(95.7)\end{array}$ & $\begin{array}{c}3 \\
(4.3)\end{array}$ & 0 & $\begin{array}{c}69 \\
(100)\end{array}$ & $\begin{array}{c}58 \\
(86.6)\end{array}$ & $\begin{array}{c}9 \\
(13.4)\end{array}$ & $\begin{array}{c}67 \\
(100)\end{array}$ \\
\hline \multicolumn{2}{|c|}{ 丁 } & $\begin{array}{c}2 \\
(2.5)\end{array}$ & $\begin{array}{c}61 \\
(77.3)\end{array}$ & $\begin{array}{c}16 \\
(20.2)\end{array}$ & $\begin{array}{c}79 \\
(100)\end{array}$ & $\begin{array}{c}50 \\
(63.3)\end{array}$ & $\begin{array}{c}29 \\
(36.7)\end{array}$ & $\begin{array}{c}79 \\
(100)\end{array}$ \\
\hline \multicolumn{2}{|c|}{ 戊十己 } & 0 & $\begin{array}{c}1 \\
(0.2)\end{array}$ & $\begin{array}{c}435 \\
(99.8)\end{array}$ & $\begin{array}{l}436 \\
(100)\end{array}$ & $\begin{array}{l}157 \\
(36.1)\end{array}$ & $\begin{array}{c}278 \\
(63.9)\end{array}$ & $\begin{array}{c}435 \\
(100)\end{array}$ \\
\hline 合 & 計 & $\begin{array}{c}68 \\
(11.7)\end{array}$ & $\begin{array}{c}65 \\
(11.1)\end{array}$ & $\begin{array}{c}451 \\
(77.2)\end{array}$ & $\begin{array}{c}584 \\
(100)\end{array}$ & $\begin{array}{l}265 \\
(45.7)\end{array}$ & $\begin{array}{c}316 \\
(54.3)\end{array}$ & $\begin{array}{c}581 \\
(100)\end{array}$ \\
\hline
\end{tabular}

埋葬者の中、年㱓の判明したものは 536 人であつて、その年齢分布は第 1 図の如く 14 歳か ら65歳に及ぶが、その中 18 歳から 25 歳までの者が特に多く全体の $61 \%$ を占め、平均年齢 は 24.8 歳である。ただし調査頭骨の中には成年に達しない個体は含なれていない。また士 官・下士官を主とする墓区甲乙丙丁と、兵を主とする墓区戊己とでは、埋葬者の平均年齡に 差が見られる。

また埋葬者の生年と死亡年の判明したものはそれぞれ 536 人、592 人で、第 2 図の如く生 年は文政元年 (1818) から明治13年（1880）に及び、死亡年は明治 6 年 (1873) から大正12 


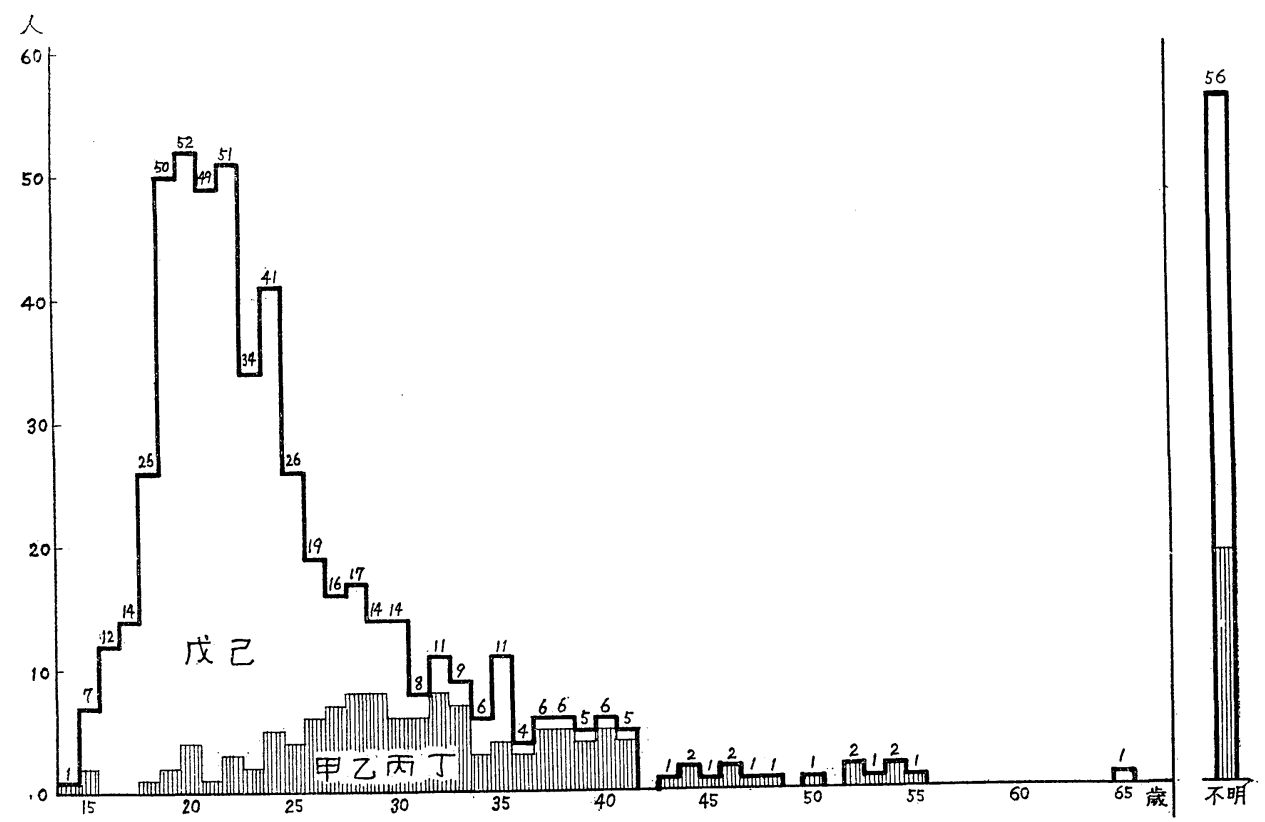

第 1 図埋葬者の年齢分布

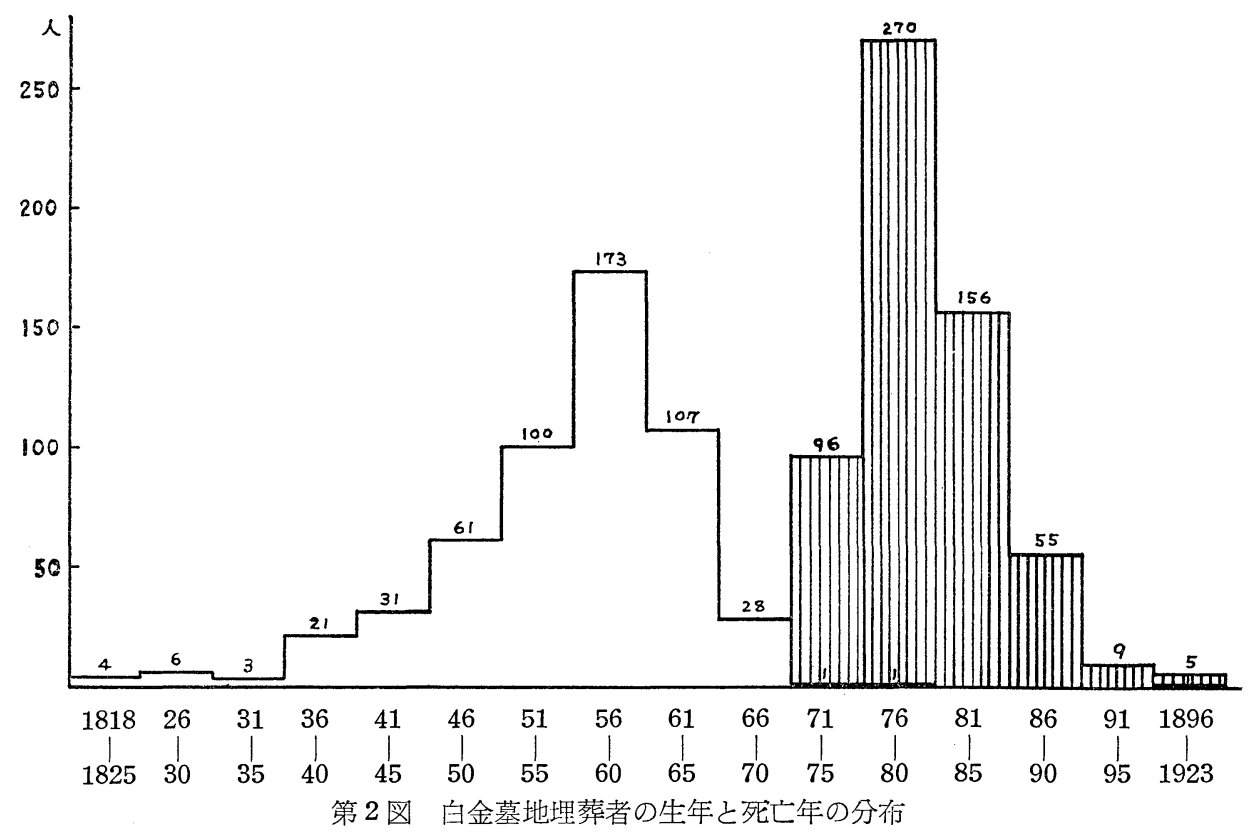

年（1923）に及ぶが、その大部分は 1841 70 年に生れ、1873 90 年に死亡した者で、即ち 幕末から明治前半にかけて生存していた人々である。

調査は墓地の発掘から再び納骨するをでの比較的短期間に終了せねばならなかつたので、 主として計測に限られた。計測は MARTIN（1928）に準拠して行い、角度の計測は正中矢状 
輪据図の図上計測法によつた。

\section{III結果拉よび比較}

1. 墓区の間の差異

白金頭骨計測值ならびに不偏分散 $\left(u^{2}\right)$ は第 2 表に一括して示されている通りである。調 第 2 表 白金頭骨計測值 $(\mathrm{mm})$

\begin{tabular}{|c|c|c|c|c|c|c|c|c|c|c|c|c|}
\hline \multirow{2}{*}{ 蕉 } & \multicolumn{3}{|c|}{ 甲乙丙丁 } & \multicolumn{3}{|c|}{ 戊己 } & \multicolumn{3}{|c|}{ 不明 } & \multicolumn{3}{|c|}{ 合計 } \\
\hline & $N$ & $\bar{x}$ & $u^{2}$ & $N$ & $\bar{x}$ & $u^{2}$ & $N$ & $\bar{x}$ & $u^{2}$ & $N$ & $\bar{x}$ & $u^{2}$ \\
\hline 2 グラべロ・イニカン長 & 19 & 170.5 & 42.3 & 14 & 166.0 & 24.7 & 128 & 167.2 & 45.1 & 161 & 167.5 & 43.8 \\
\hline 3 グラベロ・ラムダ長 & 19 & 175.4 & 32.5 & 14 & 173.4 & 21.8 & 127 & 173.1 & 37.0 & 160 & 173.3 & 35.4 \\
\hline 22a カロッテ高 & 19 & 105.3 & 48.3 & 14 & 105.0 & 32.3 & 127 & 105.3 & 28.8 & 160 & 105.2 & 30.9 \\
\hline 1 最 大 長 & 21 & 180.6 & 37.7 & 16 & 179.1 & 37.7 & 154 & 179.0 & 48.0 & 191 & 179.2 & 45.8 \\
\hline 8 最 大 幅 & 21 & 140.4 & 11.2 & 6 & .2 & 21.1 & 150 & 139.1 & 23.0 & 187 & 9.3 & 17.4 \\
\hline 17 バシオン・ブレグマ高 & 21 & 139.6 & 25.1 & 6 & 139.5 & 14.5 & 141 & 137.1 & 18.8 & 178 & 137.6 & 20.0 \\
\hline 20 耳ブレグマ高 & 19 & 115.7 & 20.5 & 13 & .2 & 5.14 & 126 & 112.7 & 17.7 & 158 & .2 & 18.5 \\
\hline 21 垂直耳高 & 18 & 116.2 & 20.3 & 14 & 11 & 11.7 & 127 & 113.1 & 22.1 & 159 & 114.1 & 21.5 \\
\hline $8: 1$ 長幅示数 & 21 & 78.5 & 13.2 & 16 & 77.3 & 12.8 & 149 & 77.9 & 14.5 & 186 & 77.9 & 14.2 \\
\hline $17: 1$ 長高示数 & 21 & 77.4 & 12.6 & 16 & 77.8 & 9.05 & 140 & 76.7 & 12.7 & 177 & 76.9 & 12.4 \\
\hline $17: 8$ 幅高示数 & 21 & 98.9 & 17.0 & 16 & 101.1 & 24.9 & 137 & 98.8 & 14.7 & 174 & 99.1 & 16.6 \\
\hline $20: 1$ 長耳ブレグマ高示数 & 19 & 64.5 & 6.94 & 13 & 64.8 & 6.26 & 125 & 63.3 & 9.12 & 157 & 3.6 & 8.81 \\
\hline$(1+8+17) / 3$ 頭昜 modulus & 21 & 153 & 11.9 & 16 & 152.3 & 8.40 & 137 & 151.5 & 14.6 & 174 & 152.9 & 14.1 \\
\hline 9 最小前頭幅 & 21 & 93.1 & 11.9 & 16 & 91.6 & 19.9 & 151 & 92.6 & 17.0 & 188 & 92.6 & 16.6 \\
\hline 10 最大前頭幅 & 21 & 11 & 25.6 & 16 & 11 & 892 & 153 & 116.1 & 20.5 & 190 & 116.2 & 20.4 \\
\hline $9: 10$ 横前頭示数 & 21 & 78.7 & 10.6 & 16 & 79.8 & 14.0 & 150 & 79.8 & 9.51 & 187 & 79.7 & 9.99 \\
\hline $9: 8$ 横前頭頭丁 & 21 & 66.0 & 8.06 & 16 & 5 & 11.3 & 146 & 66.6 & 7.71 & 183 & 66.5 & 9.46 \\
\hline 5 頭骨低長 & 21 & 101.7 & 15.5 & 16 & 10 & 5.2 & 141 & 7 & 17.1 & 178 & 100.8 & $\mathbf{1 6 . 7}$ \\
\hline 11 両耳愊 & 21 & 126.6 & 11.4 & 16 & 1 & .9 & 143 & 6 & 25.2 & 180 & 125.6 & 23.4 \\
\hline 12 最大後頭幅 & 21 & 110.4 & 21.2 & 16 & 10 & 6 & 152 & 109.2 & 20.0 & 189 & 109.3 & 20.5 \\
\hline $12: 8$ 横頭丁頁後 & 21 & 78.1 & 16.4 & 16 & $7 \varepsilon$ & 21.6 & 148 & 78.5 & 12.6 & 185 & 78.4 & 13.6 \\
\hline 13 乳 様 幅 & 20 & 103.9 & 28.0 & 14 & 103.5 & 28.9 & 133 & 102.7 & 23.0 & 167 & 102.9 & 24.4 \\
\hline 14 最小頭,骨幅 & 21 & 72.3 & 18.3 & 16 & 73.0 & 16.7 & 139 & 71.9 & 18.4 & 176 & 72.1 & 18.1 \\
\hline 7 大後頭孔長 & 21 & 35.4 & 6.05 & 16 & 36.1 & 7.13 & 134 & 35.9 & 5.57 & 171 & 35.8 & 5.73 \\
\hline 16 大後頭孔幅 & 21 & 30.4 & 3.96 & 16 & 30.3 & 2.76 & 134 & 30.3 & 3.13 & 171 & 30.3 & 3.16 \\
\hline $16: 7$ 大後頭孔示数 & 21 & 86.4 & 26.3 & 16 & 84.7 & 51.5 & 131 & 84.4 & 31.4 & 168 & 84.7 & 32.6 \\
\hline 23 水 平 周 & 21 & 515 . & 180.4 & 16 & 510.4 & 145.7 & 148 & 510.8 & 182.2 & 185 & 511.3 & 174.0 \\
\hline 24 横 弧 長 & 21 & 317 & 95.7 & 16 & 314.8 & 53.2 & 142 & 313.4 & 105.5 & 179 & 314.1 & 99.6 \\
\hline $24 \mathrm{a}$ 横 弧 長 & 21 & 306 & 131.3 & 16 & 30 & 61.3 & 142 & 303.4 & 114.1 & 179 & 303.8 & 111.5 \\
\hline 24(1) 横 全 周 & 21 & & 132.8 & 16 & 45 & 97.5 & 142 & 448.5 & 134.2 & 179 & 449.2 & 13 \\
\hline 24(3) 頭頂横弧長 & 21 & 12 & 260.2 & 16 & 119.3 & 85.8 & 150 & 118.1 & 3 & 187 & 3.5 & 15 \\
\hline 25 正中矢状弧長 & 21 & 377.7 & 173.2 & 16 & 372.3 & 151.6 & 141 & 370.6 & 153.0 & 178 & .6 & 158 \\
\hline 26 正中前頭弧長 & 21 & 129.0 & 30.0 & 16 & 126.4 & 34.9 & 159 & 125.2 & 33.8 & 196 & .7 & 34.5 \\
\hline 27 正中頭頂弧長 & 21 & 129.5 & 51.6 & 16 & 127.5 & 42.7 & 151 & 127.3 & 60.3 & 188 & 127.6 & 57.8 \\
\hline 28 正中後頭弧長 & 21 & 117.9 & 69.1 & 15 & 116.3 & 49.6 & 141 & 117.5 & 63.1 & 177 & 117.5 & 62.1 \\
\hline 28(1) 後頭上鱗弧長 & 21 & 76.9 & 50.9 & 16 & 75.9 & 85.5 & 148 & 76.9 & 71.5 & 185 & 76.8 & 65.2 \\
\hline
\end{tabular}


第 2 表（つづき）

\begin{tabular}{|c|c|c|c|c|c|c|c|c|c|c|c|c|}
\hline \multirow{2}{*}{ 墓 } & \multicolumn{3}{|c|}{ 甲乙丙丁 } & \multicolumn{3}{|c|}{ 戊已 } & \multicolumn{3}{|c|}{ 不明 } & \multicolumn{3}{|c|}{ 合計 } \\
\hline & $N$ & $\bar{x}$ & $u^{2}$ & $N$ & $\bar{x}$ & $u^{2}$ & $N$ & $\bar{x}$ & $u^{2}$ & $N$ & $\bar{x}$ & $u^{2}$ \\
\hline 28(2) 後頭下鱗弧長 & 21 & 41.1 & 14.8 & 16 & 42.1 & 21.81 & 140 & 40.6 & 24.1 & 177 & 40.8 & 24.0 \\
\hline $27: 26$ 矢状前頭頭頂示数 & 21 & 100.5 & 34.9 & 16 & 101.2 & 67.11 & 151 & 101.7 & 60.4 & 1881 & 101.6 & 57.7 \\
\hline 28(1) : 28 後頭弧長示数 & 21 & 64.5 & 17.2 & 15 & 64.1 & $18.4 \cdot 1$ & 140 & 65.3 & 19.5 & 176 & 65.1 & 19.1 \\
\hline 29 正中前頭弦長 & 21 & 113.5 & 14.8 & 16 & 111.9 & 20.91 & 160 & 110.8 & 20.9 & 197 & 111.2 & 20.8 \\
\hline 30 正中頭頂弦長 & 21 & 115.0 & 30.2 & 16 & 113.9 & 22.11 & 152 & 113.4 & 38.1 & 189 & 113.7 & 35.8 \\
\hline 31 正中後頭弦長 & 21 & 99.6 & 31.4 & 16 & 100.9 & 40.51 & 140 & 99.3 & 29.9 & 177 & 99.5 & 30.8 \\
\hline 31(1) 後頭上鱗弦長 & 21 & 70.8 & 35.7 & 16 & 70.5 & 69.31 & 148 & 71.1 & 51.0 & 185 & 71.0 & 50.7 \\
\hline 31(2) 後頭下鱗弦長 & 21 & 40.3 & 16.9 & 16 & 41.6 & 18.91 & 140 & 39.9 & 21.6 & 177 & 40.1 & 21.4 \\
\hline $31: 12$ 後頭鱗幅高示数 & 21 & 90.3 & 31.9 & 16 & 92.3 & 39.51 & 137 & 91.0 & 29.5 & 174 & 91.1 & 30.4 \\
\hline $29: 26$ 矢状前頭示数 & 21 & 88.0 & 3.56 & 16 & 88.6 & 1.581 & 159 & 88.5 & 3.06 & 196 & 88.4 & 2.98 \\
\hline $30: 27$ 矢状頭頂示数 & 21 & 89.0 & 3.16 & 16 & 89.4 & 3.001 & 151 & 89.0 & 4.14 & 188 & 89.0 & 3.91 \\
\hline $31: 28$ 矢状後頭示数 & 21 & 84.6 & 6.09 & 15 & 85.5 & 4.50 & 140 & 84.6 & 7.34 & 176 & 84.7 & 6.96 \\
\hline $31(1): 28(1)$ 上鱗弯曲示数 & 21 & 92.3 & 3.76 & 16 & 92.7 & 3.13 & 148 & 92.6 & 5.94 & 185 & 92.5 & 5.42 \\
\hline 32 前頭側面角 & 19 & 85.6 & 30.9 & 14 & 85.1 & 11.6 & 130 & 85.0 & 23.8 & 163 & 85.1 & 23.2 \\
\hline 32(1) 前頭傾斜角 & 18 & 63.0 & 10.4 & 13 & 63.9 & 5.10 & 125 & 64.2 & 8.63 & 156 & 64.1 & 8.60 \\
\hline 32(1a) 前頭傾斜角 & 18 & 50.5 & 11.6 & 13 & 50.8 & 10.2 & 126 & 50.8 & 8.17 & 157 & 50.8 & 8.60 \\
\hline 32(5) 前頭弯曲角 & 18 & 131.2 & 14.3 & 13 & 131.1 & 9.1 & 126 & 131.4 & 25.8 & 157 & 131.4 & 23.0 \\
\hline 33 ラムダ・オピスチオン角 & 17 & 119.4 & 16.0 & 14 & 120.1 & 23.9 & 122 & 118.8 & 15.8 & 153 & 119.0 & 16.5 \\
\hline 33(1) ラム多・イ二オン角 & 18 & 100.0 & 39.2 & 14 & 99.0 & 39.4 & 126 & 100.0 & 24.4 & 158 & 99.9 & 27.0 \\
\hline 33(2) オピスチオン・゙ン & 18 & 26.6 & 36.3 & 14 & 26.9 & 36.6 & 124 & 25.9 & 36.3 & 156 & 26.0 & 36.9 \\
\hline 33(4) 後頭屈曲角 & 19 & 127.6 & 40.7 & 14 & 125.6 & 51.41 & 1231 & 125.4 & 41.5 & 156 & 125.7 & 42.2 \\
\hline 40 顔 長 & 19 & 96.0 & 19.7 & 16 & 96.9 & 34.11 & 136 & 97.8 & 27.2 & 171 & 97.5 & 27.1 \\
\hline $40: 5$ 顎 示 数 & 19 & 94.9 & 16.5 & 16 & 96.5 & 21.01 & 137 & 97.4 & 15.7 & 172 & 97.0 & 16.7 \\
\hline 44 両眼窩幅 & 19 & 96.0 & 12.8 & 16 & 96.6 & 12.31 & 147 & 97.0 & 15.3 & 182 & 96.8 & 14.7 \\
\hline 44(1) 鼻 頼 幅 & 18 & 106.0 & 18.7 & 16 & 104.9 & 13.9 & 146 & 104.8 & 20.1 & 180 & 104.9 & 19.3 \\
\hline 44(1): 44 鼻 頓示 数 & 18 & 110.5 & 5.94 & 16 & 108.8 & 3.43 & 147 & 108.1 & 7.20 & 181 & 108.4 & 7.19 \\
\hline 43 上 顔 幅 & 21 & 103.5 & 6.96 & 16 & 102.4 & 17.2 & 152 & 103.7 & 14.6 & 189 & 103.6 & 14.0 \\
\hline $9: 43$ 前頭両腿窝示数 & 21 & 90.2 & 11.1 & 16 & 89.4 & 2.46 & 148 & 89.4 & 9.56 & 185 & 89.5 & 9.11 \\
\hline 45 頓 弓 愊 & 19 & 132.5 & 18.0 & 16 & 131.8 & 39.8 & 131 & 133.8 & 26.7 & 166 & 133.5 & 27.2 \\
\hline 46 中 顔 幅 & 19 & 98.8 & 14.3 & 16 & 98.3 & 17.0 & 142 & 98.9 & 26.0 & 177 & 98.8 & 23.8 \\
\hline 48 上 顔 高 & 18 & 71.2 & 21.0 & 16 & 70.3 & 14.7 & 153 & 70.1 & 14.0 & 187 & 70.2 & 14.7 \\
\hline $48: 45$ コルマンの上顔示数 & 19 & 53.8 & 14.5 & 16 & 53.3 & 12.7 & 129 & 52.5 & 8.12 & 164 & 52.7 & 9.35 \\
\hline $48: 46$ ウィルヒョウ & 19 & 72.9 & 29.9 & 16 & 71.6 & 17.7 & 142 & 71.2 & 19.9 & 177 & 71.4 & 20.8 \\
\hline $9: 45$ 頼前頭示数 & 19 & 70.4 & 15.2 & 16 & 69.5 & 9.80 & 131 & 69.1 & 11.2 & 166 & 69.3 & 11.5 \\
\hline $45: 8$ 横頭顔示数 & 19 & 93.5 & 14.8 & 16 & 95.8 & 21.7 & 126 & 96.2 & 18.1 & 161 & 95.9 & 18.7 \\
\hline $49 \mathrm{a}$ 眼 間 幅 & 20 & 20.2 & 2.13 & 16 & 20.3 & 3.43 & 151 & 21.0 & 6.01 & 187 & 20.9 & 5.44 \\
\hline 50 前眼㸗間幅 & 20 & 18.0 & 2.11 & 16 & 17.9 & 1.58 & 152 & 18.0 & 5.22 & 188 & 18.0 & 4.56 \\
\hline $50: 44$ 眼窩間示数 & 19 & 18.7 & 2.98 & 16 & 18.5 & 1.66 & 144 & 18.4 & 4.69 & 9179 & 18.4 & 4.25 \\
\hline 51 眼窝幅 (太) & 18 & 42.4 & 2.84 & 16 & 42.2 & 2.70 & 147 & 42.4 & 4.63 & 181 & 42.4 & 4.25 \\
\hline 52 眼營高（吉） & 18 & 33.9 & 4.22 & 16 & 33.9 & 2.86 & 145 & 34.4 & 2.92 & 179 & 34.3 & 3.04 \\
\hline $52: 51$ 眼简示数 (大) & 18 & 79.6 & 16.0 & 16 & 80.8 & 19.5 & 145 & 81.3 & 25.7 & 179 & 81.0 & 24.2 \\
\hline 54 鼻 & 19 & 26.0 & 3.89 & 16 & 25.1 & 1.53 & 152 & 25.7 & 3.83 & 187 & 25.7 & 3.66 \\
\hline 55 鼻 & 19 & 52.9 & 10.4 & 16 & 52.2 & 10.4 & 152 & 52.2 & 7.4 & 187 & 52.2 & 7.93 \\
\hline
\end{tabular}


第 2 表（つづき）

\begin{tabular}{|c|c|c|c|c|c|c|c|c|c|c|c|c|}
\hline \multirow{2}{*}{ 墓 } & \multicolumn{3}{|c|}{ 昌乙㐫丁 } & \multicolumn{3}{|c|}{ 戊己 } & \multicolumn{3}{|c|}{ 不明 } & \multicolumn{3}{|c|}{ 合計 } \\
\hline & $N$ & $\bar{x}$ & $u^{2}$ & $N$ & $\bar{x}$ & $u^{2}$ & $N$ & $\bar{x}$ & $u^{2}$ & $N$ & $\bar{x}$ & $u^{2}$ \\
\hline $54: 55$ 鼻 示 数 & 19 & 49.1 & 20.1 & 16 & 48.0 & 13.2 & 150 & 49.4 & $14 \cdot 7$ & 185 & 49.3 & 17.3 \\
\hline $55(1)$ 梨状口高 & 15 & 32.4 & 7.40 & 15 & 32.1 & 3.21 & 113 & 31.8 & 5.47 & 143 & 31.9 & 5.68 \\
\hline $54: 55$ (1) 梨状口高幅示数 & 15 & 81.4 & 84.4 & 15 & 78.1 & 34.5 & 112 & 81.4 & 78.8 & 142 & 81.0 & 75.2 \\
\hline 57 舅骨最小幅 & 19 & 7.6 & 1.58 & 16 & 6.8 & 3.29 & 153 & 7.2 & 3.25 & 188 & 7.2 & 3.21 \\
\hline 57(1) 鼻骨最大幅 & 19 & 17.2 & 3.73 & 15 & 17.6 & 1.69 & 129 & 17.8 & 3.62 & 163 & 17.6 & 3.60 \\
\hline $57: 57(1)$ 横嘼骨示数 & 19 & 44.2 & 47.7 & 15 & 38.4 & 105.4 & 129 & 40.3 & 90.0 & 163 & 40.6 & 90.1 \\
\hline $57(2)$ 鼻高上幅 & 19 & 10.4 & 4.36 & 16 & 9.7 & 10.9 & 152 & 10.0 & 7.6 & 187 & 10.0 & 7.50 \\
\hline 57(3) 鼻骨下幅 & 19 & 16.8 & 2.70 & 16 & 16.7 & 2.23 & 129 & 17.5 & 3.22 & 164 & 17.4 & 3.19 \\
\hline 60 上顎歯槽長 & 18 & 51.6 & 4.14 & 16 & 50.7 & 18.9 & 137 & 52.0 & 8.85 & 5171 & 51.7 & 9.52 \\
\hline 61 上顎歯槽幅 & 18 & 66.0 & 5.53 & 15 & 65.5 & 9.12 & 143 & 66.0 & 12.8 & 176 & 65.9 & 11.7 \\
\hline $61: 60$ 上顎莜槽示数 & 18 & 127.8 & 20.3 & 15 & 132.4 & 231.7 & 136 & 128.0 & 64.3 & 169 & 128.3 & 68.9 \\
\hline $61(2)$ 上頢前歯槽幅 & 18 & 42.3 & 6.09 & 15 & 41.9 & 9.78 & 145 & 42.8 & 8.39 & 9178 & 42.7 & 8.25 \\
\hline 62 口蓋 長 & 18 & 44.1 & 4.17 & 16 & 44.6 & 10.3 & 141 & 44.9 & 9.56 & 6175 & 44.7 & 9.04 \\
\hline 63 口㥺幅 & 18 & 40.3 & 5.74 & 16 & 40.3 & 9.63 & 146 & 40.8 & 6.67 & 7180 & 40.7 & 6.79 \\
\hline $63: 62$ 口蓋示数 & 18 & 91.6 & 46.1 & 16 & 91.1 & 105.3 & 139 & 91.6 & 57.6 & 173 & 91.6 & 60.0 \\
\hline 64 口蓋 高 & 18 & 11.0 & 6.24 & 15 & 10.3 & 3.38 & 131 & 11.5 & 3.61 & 164 & 11.4 & 4.00 \\
\hline 72 全側面角 & 19 & $85.8^{\circ}$ & 11.9 & 13 & $82.4^{\circ}$ & 17.6 & 122 & $82.8^{\circ}$ & 10.8 & 154 & $83.1^{\circ}$ & 12.4 \\
\hline 73 鼻側面角 & 16 & $92.4^{\circ}$ & 18.5 & 12 & $88.2^{\circ}$ & 26.3 & 113 & $88.5^{\circ}$ & 14.8 & 141 & $88.9^{\circ}$ & 17.5 \\
\hline 74 菡槽側面角 & 16 & $69.1^{\circ}$ & 113.7 & 12 & $66.7^{\circ}$ & 118.2 & 110 & $65.2^{\circ}$ & 56.1 & 138 & $65.8^{\circ}$ & 68.2 \\
\hline
\end{tabular}

査可能の頭骨のうち、発掘された墓区が明らかであつたものは比較的少数であつたが、前述 したように墓区によつて埋葬者の階級、身分などの性質が異る。そこで墓区の明らかな頭骨 については、士官拈よび下士官を主とする甲乙丙丁の 4 墓区と、兵を主とする戊己の 2 墓区 とを別に集計した結果を第 2 表に併記してある。

この 2 群の計測值を比較すると、多くの項目に物いては大差が見られず、また差のある項 目でも、例数が少いために確実なことは言えない。しかし比較的差が大きいように見える項 目のらち、主要なものについて次に述べる。

脳頭骨の大きさを示す頭骨 modulus では第 1 群（甲乙丙丁）が第 2 群（戊己）よりをや や大きい。これは最大長。最大幅ともに第 1 群の方が大きいことによるが、この両者のうち 特に最大幅の差が大きい。これと一致して最小前頭幅、最大前頭幅、両耳幅、最大後頭幅な ぞの脳頭骨の幅径に执いて、すべて第 1 群が優つている。したがつて長幅示数でもやや第 1 群の方が大きいが、幅高示数では逆汇第 2 群の方が大きい。

さらに水平周、横弧長。正中矢状弧長などの弧長に拈いても、全般的に第 1 群の方が大で ある。

颜面頭骨の計測では、第 1 群の方が VIRCHOW の上顔示数が大きく、より狭顔に傾くよう に見觉る。

顔面角は全側面角、舅側面角、歯槽側面角のいずれも第 1 群の方が大きく、したがつて正 顎汇近い。

2. 時代別の資料との比較

白金頭骨の計測值を日本人形質の時代的变逗の中に位置づけるために、鎌倉時代より現代 
東京都芝白金、旧海軍墓地に埋葬された江戸末、明治初年の日本人頭骨

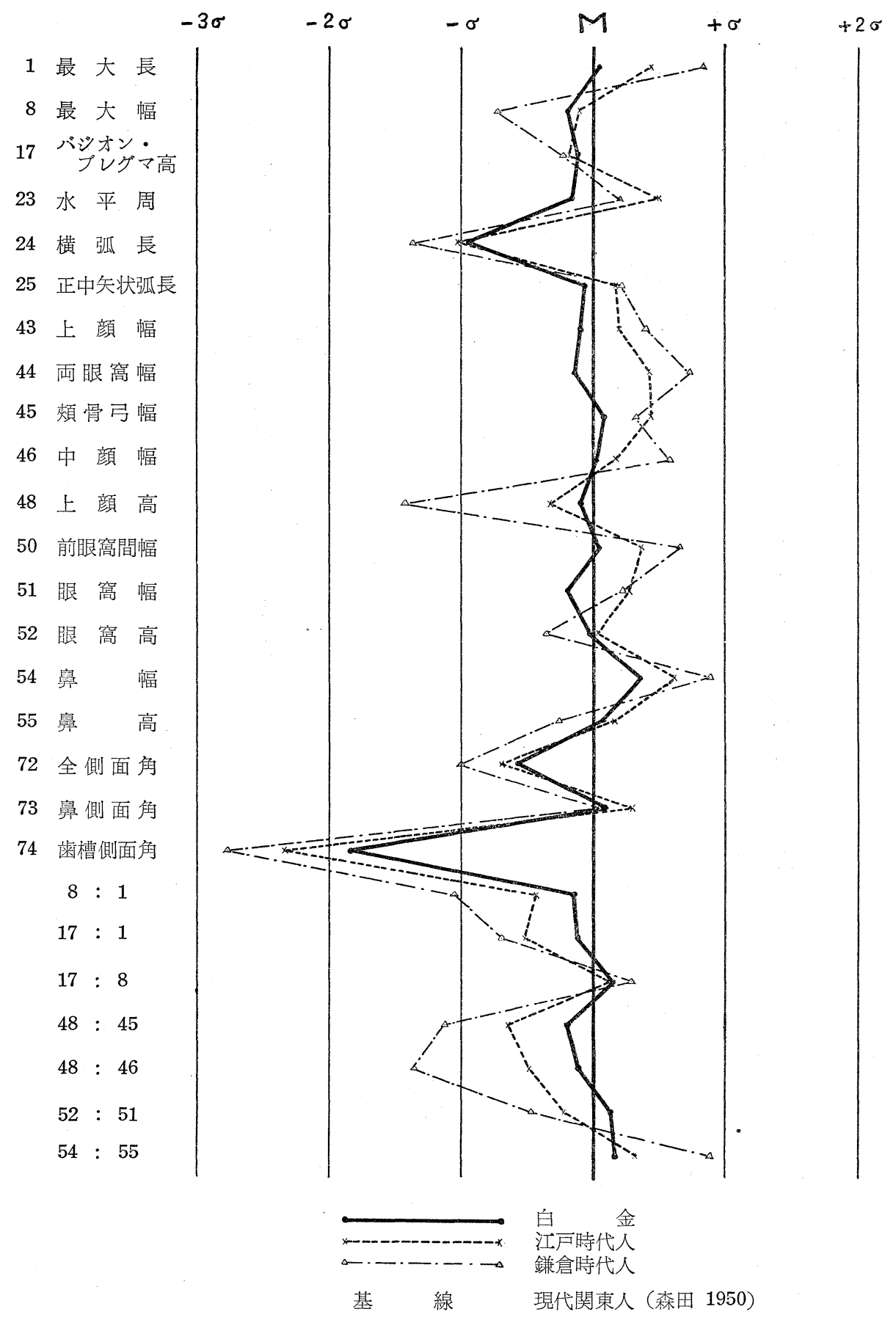

第 3 図 偏差折線による時代別の頭骨計測値の比較 
に至る男性の時代別の資料と比較した結果を次に述べる。比較資料としては、鈴木その他に よる関東地方の鎌倉特代、(1956)、室町時代人 (1958)、江戸時代人 (1957) および森田 (19 50）の現代関東人についての計測值を選んだ。また、白金墓地埋葬者の出身地が西日本に偏 つていることを考慮して、参考のために原田（1954）による西南日本人の計測値とも比較し た。ただし原田の資料は玄海、瀬戸内海、有明海沿岸地方の出身者を合算したものであつて、

第 3 表 脳頭骨計測値の比較 $(\mathrm{mm})$

$u$ は標準偏差不偏推定佔。《、く、（） はそれぞれ 1\%、5％、10\% の有意水準

における白金と江戸時代または現代との間の差を示す。＊3 径の平均値より算出。

\begin{tabular}{|c|c|c|c|c|c|c|c|c|c|}
\hline & & $\begin{array}{l}\text { 蟬倉時代 } \\
\text { (鈴木䛧) }\end{array}$ & $\begin{array}{l}\text { 瑏町時代 } \\
\text { (鈴木悑) }\end{array}$ & 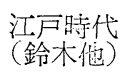 & & 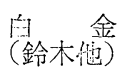 & & $\begin{array}{l}\text { 現 代 } \\
\text { (森 } \text { 田) }\end{array}$ & $\begin{array}{l}\text { 画店日本 } \\
\text { (原田) }\end{array}$ \\
\hline \multirow{3}{*}{1 頭罱最大長 } & $N$ & 170 & 67 & 165 & \multirow{3}{*}{$\gg$} & 191 & & 143 & 108 \\
\hline & $\bar{x}$ & 184.2 & 183.6 & 181.9 & & 179.2 & & 178.9 & 181.4 \\
\hline & $u$ & 7.69 & 5.15 & 6.64 & & 6.77 & & 6.55 & 6.71 \\
\hline \multirow{3}{*}{8 頭骨鼠大愊 } & $N$ & 164 & 66 & 161 & & 187 & \multirow{3}{*}{$<$} & 143 & 103 \\
\hline & $\bar{x}$ & 136.5 & 138.7 & 139.8 & & 139.3 & & 140.3 & 139.3 \\
\hline & $u$ & 5.60 & 4.59 & 4.79 & & 4.17 & & 5.23 & 4.64 \\
\hline \multirow{3}{*}{$\begin{aligned} 17 & \text { バシオン・ } \\
& \text { ブレゲマ高 }\end{aligned}$} & $N$ & 96 & 49 & 140 & & 178 & & 143 & 108 \\
\hline & $\bar{x}$ & 137.2 & 136.6 & 137.5 & & 137.6 & & 138.1 & 139.3 \\
\hline & $u$ & 5.99 & 5.37 & 4.88 & & 4.47 & & 4.68 & 4.57 \\
\hline \multirow{3}{*}{$\begin{array}{l}(1+8+17) / 3 \\
\text { 頭骨 modulus }\end{array}$} & $N$ & 88 & 47 & 136 & & 174 & & 143 & 108 \\
\hline & $\bar{x}$ & 152.4 & 152.9 & 153.1 & & 152.9 & & 152.8 & $153.3^{*}$ \\
\hline & $u$ & 4.55 & 3.89 & 3.56 & & 3.75 & & 4.01 & \\
\hline \multirow{3}{*}{$8: 1$} & $N$ & 164 & 61 & 160 & & 178 & & 143 & 108 \\
\hline & $\bar{x}$ & 74.2 & 75.9 & 76.9 & $\ll$ & 77.9 & & 78.5 & 76.6 \\
\hline & $u$ & 4.10 & 3.48 & 3.73 & & 3.77 & & 3.93 & 3.74 \\
\hline \multirow{3}{*}{$\begin{array}{ll}17: 1 & \text { 頭骨長高 } \\
\text { 示数 }\end{array}$} & $N$ & 94 & 48 & 139 & & 177 & & 143 & 108 \\
\hline & $\bar{x}$ & 75.0 & 74.7 & 75.6 & $\ll$ & 76.9 & & 77.3 & 76.9 \\
\hline & $u$ & 3.24 & 2.94 & 3.64 & & 3.52 & & 3.28 & 3.17 \\
\hline \multirow{3}{*}{ 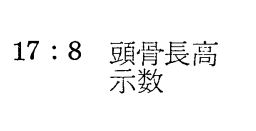 } & $N$ & 93 & 49 & 138 & & 174 & & 143 & 108 \\
\hline & $\bar{x}$ & 99.8 & 97.9 & 98.6 & & 99.1 & & 98.6 & 100.1 \\
\hline & $u$ & 5.27 & 4.08 & 3.85 & & 4.07 & & 4.16 & 3.67 \\
\hline \multirow{3}{*}{23 頭骨水平周 } & $N$ & 151 & 50 & 156 & & 185 & & 142 & 108 \\
\hline & $\bar{x}$ & 516.9 & 521.8 & 520.2 & $\gg$ & 511.3 & & 513.7 & 514.6 \\
\hline & $u$ & 14.70 & 11.96 & 14.04 & & 13.19 & & 15.00 & 14.47 \\
\hline \multirow{3}{*}{24 横 弧 長 } & $N$ & 127 & 47 & 142 & & 179 & & 143 & 108 \\
\hline & $\bar{x}$ & 309.4 & 308.9 & 313.1 & & 314.1 & $\ll$ & 324.4 & 315.5 \\
\hline & $u$ & 11.00 & 9.42 & 10.39 & & 9.98 & & 10.70 & 9.32 \\
\hline \multirow{3}{*}{25 正中矢状弧長 } & $N$ & 111 & 53 & 150 & & 178 & & 143 & 108 \\
\hline & $\bar{x}$ & 373.7 & 371.5 & 373.4 & & 371.6 & & 371.7 & 378.0 \\
\hline & $u$ & 14.75 & 13.36 & 11.85 & & 11.58 & & 12.55 & 13.17 \\
\hline
\end{tabular}


鹿児島県などの南九州出身者は含まれていないのに反し、白金墓地埋葬者の出身地は鹿児島 県が最も多く、また比較的少数ながら日本全国低つているなどの点で比較の上飞難点があ ることを考光に入れなければならない。

白金頭骨とこれら各時代の頭骨との主要な計測值の比較は第 3 表ならびに第 4 表に示す通 りである。また、これらのらち鎌倉時代人、江戸時代人扔よび白金頭骨の数值を、現代人（森 田、1950）を基線とする MOLLISON-MARTIN の偏差折線に描いて第 3 四に示す。この眓 から大観されるょうに、多くの項目に乱いて計測值の大きさは鎌倉・江戸・白金・現代の順 飞並んでおり、白金頭骨は年代の上でも計測值の上でもほぼ江戸時代と現代人との中間位 置することが知られる。次主要な数值についてこれらの関係を述べる。

脳頭骨の大きさ：

頭骨 modulus の值から知られる脳頭骨の大ささは、第 3 表に見られる如く時代別の群の 間で大差がない。白金頭骨に执いても各時代群の変異の間にあり、また西南日本人とも大差 が見られない。

脳頭骨の 3 主径：

頭骨最大長は鎌倉時代以降、時代を追つて隇少するが、白金頭骨の值は江戸時代人と現代 関束人との中間にあつて現代により近く、江戸時代人との差は有意である。西南日本人の值 は白金より却つて大きく、江戸時代人に近い。

頭骨最大幅は時代と共飞增加する傾向にあるが、白金頭骨の值は最大長の場合と異り、江 戸時代人々ほほぼ等しく、現代関東人より有意に小さい。また西南日本人とは差がない。

頭骨長幅示数は時代と共飞增加するが、白金頭骨の値は江戸時代人と現代関東人との中問 にあつて、現代により近く、江戸時代人よりは有意に大さい。西南日本人の值は白金頭骨よ りも却って小さく、江可時代人に近い。

バシオン・ブレグマ高は江戸時代人に近いが現代関東人との間にも有意差がない。西南日 本人は現代関東人よりも更に大きい。

頭骨長高示数は室町時代以後增加の傾向があり白金頭骨の值は江戸時代人と現代関東人と の中間にあるが、江戸時代人との差は有意である。西南日本人との間には差がない。

頭骨幅高示数は時代差が不明瞭で、白金頭骨の值は江戸時代人、現代関東人のいずれとも 有意差がない。

脳頭骨の周径战よび弧長：

頭骨水平周は鎌倉時代人々室町時代人との間で増加し、それ以後隇少の傾向がある。殊飞 江戸時代人と現代関東人との間には大きな差が見られるがこの変化は主として、後者の幅径 が前者より有意の差をむつて大きいが、それにも增して後者は長径の減少が著しいことに起 因していると考完られる。

白金頭骨の水平周は江.戸時代人上りも有意に小さく、現代関東人上りも更に幾分小さいが その差は有意でない。この白金頭骨の水平周が小さい事実は、長径の隇少に秥いてはすでに 江戸時代人の值を離れて現代人に近づいて和り、一方幅径は未だ現代人の值に達していない ことから来る当然の結果である。西南日本人の值は現代関東人に近いが、白金頭骨よりは有 意汇大きく、江戸時代人よりはかなり小さい。

横弧長は室町時代以降増加の傾向があり、白金頭骨の值は現代関東人よりも有意に小さく、 
むしろ江戸時代人に近い。すた西南日本人とも大差がない。

正中矢状弧長はこれと異り、現代関東人と同等であるが、江戸時代人との間にも有意差は ない。西南日本人の值は他のいずれよりもとび離れて大きい。

顔面頭骨の幅径と高径 :

上顔幅、中顔幅、頓弓幅なぞの顔面頭骨の幅径は第 4 表に見られるように概して時代と共 飞減少している。煩弓幅のみは室町時代人の值は鎌倉時代よりも却つて大きくなつている

第 4 表 顔面頭骨計測值の比較 $(\mathrm{mm})$

記号は第 3 表に同じ。

\begin{tabular}{|c|c|c|c|c|c|c|c|c|}
\hline & & $\begin{array}{l}\text { 鎌倉時代 } \\
\text { (鈴木他) }\end{array}$ & $\begin{array}{l}\text { 室町時代 } \\
\text { (鈴木他) }\end{array}$ & $\begin{array}{l}\text { 江戸時代 } \\
\text { (鈴木他边) }\end{array}$ & & $\begin{array}{l}\text { (鈴木他金) } \\
\text { (1) }\end{array}$ & $\begin{array}{l}\text { 現 代 } \\
\text { (森 田) }\end{array}$ & 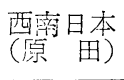 \\
\hline 43 上 顔 幅 & $\begin{array}{l}N \\
\bar{x} \\
u\end{array}$ & $\begin{array}{r}118 \\
105.5 \\
3.66\end{array}$ & $\begin{array}{r}58 \\
104.9 \\
4.07\end{array}$ & $\begin{array}{r}121 \\
104.8 \\
3.60\end{array}$ & $\gg$ & $\begin{array}{r}189 \\
103.6 \\
3.74\end{array}$ & $\begin{array}{r}144 \\
103.8 \\
4.10\end{array}$ & $\begin{array}{l}108 \\
104.7 \\
3.92\end{array}$ \\
\hline 44 両限窝幅 & $\begin{array}{l}N \\
\bar{x} \\
u\end{array}$ & $\begin{array}{r}101 \\
100.0 \\
3.79\end{array}$ & $\begin{array}{l}47 \\
99.4 \\
3.96\end{array}$ & $\begin{array}{c}108 \\
98.8 \\
3.38\end{array}$ & $\gg$ & $\begin{array}{r}182 \\
96.8 \\
3.83\end{array}$ & $\begin{array}{r}144 \\
97.2 \\
3.80\end{array}$ & $\begin{array}{l}108 \\
97.9 \\
3.65\end{array}$ \\
\hline 46 中 顔 幅 & $\begin{array}{l}N \\
\bar{x} \\
u\end{array}$ & $\begin{array}{r}107 \\
101.8 \\
5.06\end{array}$ & $\begin{array}{r}46 \\
101.6 \\
4.44\end{array}$ & $\begin{array}{r}107 \\
99.6 \\
4.86\end{array}$ & & $\begin{array}{r}177 \\
98.8 \\
4.88\end{array}$ & $\begin{array}{r}143 \\
98.6 \\
5.16\end{array}$ & $\begin{array}{l}107 \\
99.9 \\
5.09\end{array}$ \\
\hline 45 檟 尸 愊 & $\begin{array}{l}N \\
\bar{x} \\
u\end{array}$ & $\begin{array}{r}96 \\
134.8 \\
6.48\end{array}$ & $\begin{array}{r}38 \\
136.0 \\
4.49\end{array}$ & $\begin{array}{r}109 \\
135.4 \\
4.89\end{array}$ & $\gg$ & $\begin{array}{r}166 \\
133.5 \\
5.22\end{array}$ & $\begin{array}{r}144 \\
132.9 \\
5.75\end{array}$ & $\begin{array}{l}106 \\
134.5 \\
4.69\end{array}$ \\
\hline 48 上 顔 高 & $\begin{array}{l}N \\
\bar{x} \\
u\end{array}$ & $\begin{array}{l}119 \\
64.7 \\
4.43\end{array}$ & $\begin{array}{l}44 \\
68.7 \\
4.17\end{array}$ & $\begin{array}{l}102 \\
69.3 \\
3.75\end{array}$ & $(<)$ & $\begin{array}{r}187 \\
70.2 \\
3.83\end{array}$ & $\begin{array}{r}144 \\
70.7 \\
4.21\end{array}$ & $\begin{array}{l}92 \\
71.8 \\
4.31\end{array}$ \\
\hline $48: 45 \begin{array}{c}\text { KOLLMANN } \\
\text { 顏示数 }\end{array}$ & $\begin{array}{l}N \\
\bar{x} \\
u\end{array}$ & $\begin{array}{l}87 \\
49.6 \\
3.67\end{array}$ & $\begin{array}{l}34 \\
50.9 \\
2.94\end{array}$ & $\begin{array}{l}95 \\
51.1 \\
3.08\end{array}$ & $\ll$ & $\begin{array}{l}164 \\
52.7 \\
3.06\end{array}$ & $\begin{array}{l}144 \\
53.3 \\
3.34\end{array}$ & $\begin{array}{l}90 \\
53.5 \\
3.41\end{array}$ \\
\hline $\begin{array}{cc} & \text { V1RCHOW } \\
& \text { の } \\
& \text { 上顔示数 }\end{array}$ & $\begin{array}{l}N \\
\bar{x} \\
u\end{array}$ & $\begin{array}{l}97 \\
65.6 \\
5.35\end{array}$ & $\begin{array}{l}41 \\
67.7 \\
4.33\end{array}$ & $\begin{array}{l}92 \\
69.7 \\
5.11\end{array}$ & $\ll$ & $\begin{array}{l}177 \\
71.4 \\
4.56\end{array}$ & $\begin{array}{r}143 \\
71.8 \\
4.62\end{array}$ & $\begin{array}{l}91 \\
71.8 \\
5.14\end{array}$ \\
\hline 51 眼筥幅 (左) & $\begin{array}{l}N \\
\bar{x} \\
u\end{array}$ & $\begin{array}{l}111 \\
43.1 \\
2.24\end{array}$ & $\begin{array}{l}46 \\
43.2 \\
1.69\end{array}$ & $\begin{array}{l}117 \\
43.2 \\
1.92\end{array}$ & $\gg$ & $\begin{array}{r}181 \\
42.4 \\
2.06\end{array}$ & $\begin{array}{l}142 \\
42.7 \\
1.74\end{array}$ & $\begin{array}{l}108 \\
43.0 \\
1.75\end{array}$ \\
\hline 52 眼窩高（志） & $\begin{array}{l}N \\
\bar{x} \\
u\end{array}$ & $\begin{array}{l}99 \\
33.7 \\
2.34\end{array}$ & $\begin{array}{l}46 \\
34.4 \\
2.04\end{array}$ & $\begin{array}{l}117 \\
34.4 \\
1.84\end{array}$ & & $\begin{array}{l}179 \\
34.3 \\
1.74\end{array}$ & $\begin{array}{l}144 \\
34.3 \\
1.78\end{array}$ & $\begin{array}{l}108 \\
34.4 \\
1.75\end{array}$ \\
\hline 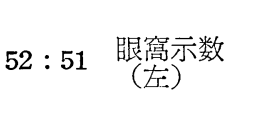 & $\begin{array}{l}N \\
\bar{x} \\
u\end{array}$ & $\begin{array}{l}96 \\
78.2 \\
4.65\end{array}$ & $\begin{array}{l}43 \\
79.1 \\
4.44\end{array}$ & $\begin{array}{l}117 \\
79.5 \\
4.68\end{array}$ & $\ll$ & $\begin{array}{l}179 \\
81.0 \\
4.92\end{array}$ & $\begin{array}{r}142 \\
80.4 \\
4.61\end{array}$ & $\begin{array}{l}108 \\
80.2 \\
4.23\end{array}$ \\
\hline
\end{tabular}


第 4 表（つづき）

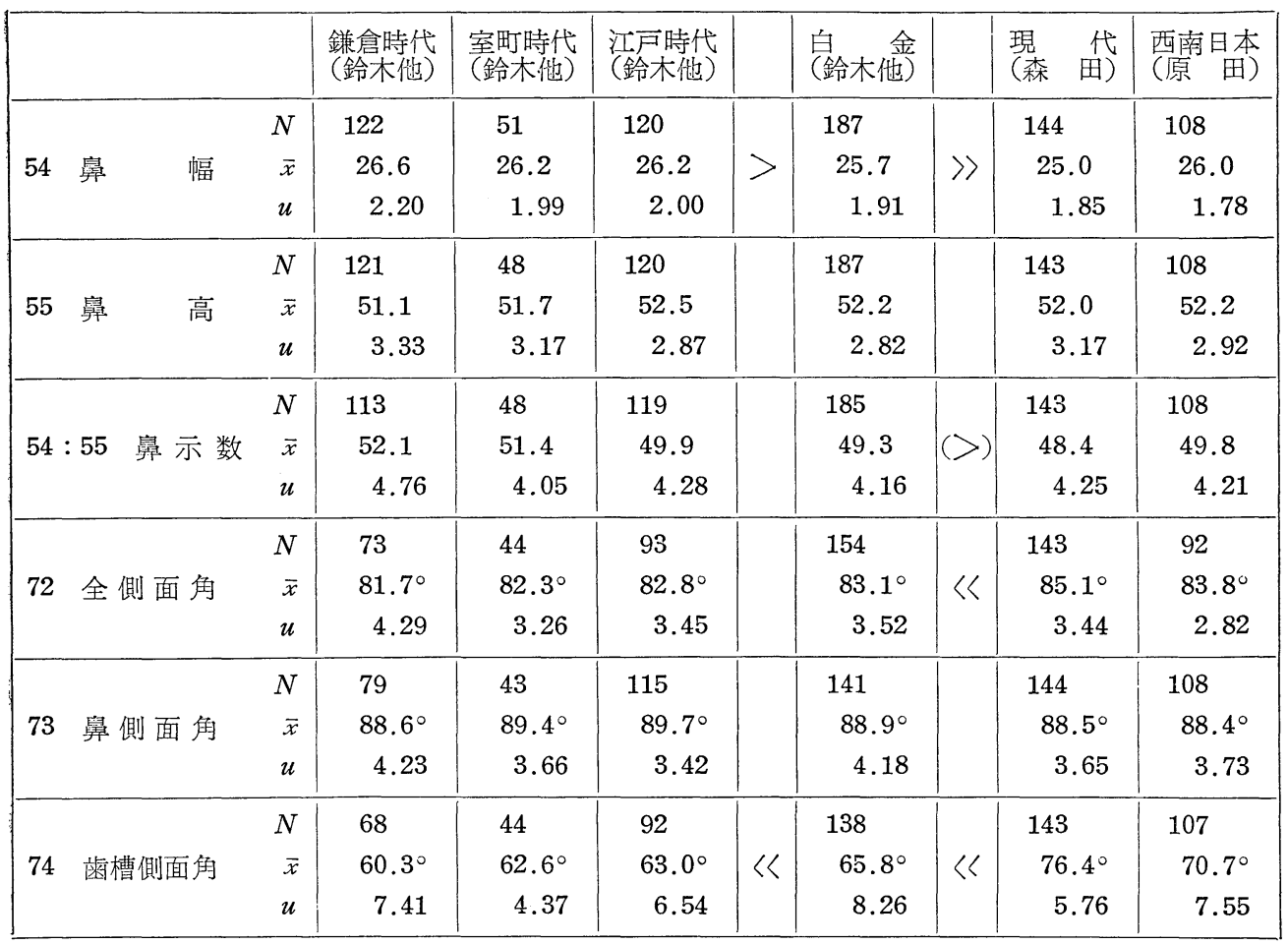

が、それ以後は減少の傾向が明らかである。この間にあつて白金頭骨の值は概ね江戸時代人 よりも小さく、現代関東人に近い。このうち上顔幅と煩弓幅に抢引る江戸時代人との差は有 意である。西南日本人の值はやや大きく、江戸時代人に近いが、上顔幅のみは白金頭骨と有 意差がある。

上顔高は時代と共に増加する。白金頭骨の值は江戸時代人と現代関東人との中間にある が、さしろ現代関東人の方に近い。西南日本人の值は現代関東人よりも更に大きく、白金頭 骨との差は有意である。

KOLLMANN の上顔示数およびVIRCHOW の上顔示数もまた時代と共に増加する。白金頭 骨の值はやはり江戸時代人と現代関東人との中間にあるが、現代関東人に近く、江戸時代人 よりはいずれも有意差をもつて大きい。西南日本人の值は両示数とも現代関東人と同等であ る。

両眼窩幅は他の幅径と同じく時代を追こて減少する。白金頭骨の值は江戸時代人ょりも有 意に小さく、また現代関東人よりるやや小さいが有意差はない。西南日本人の值は汀戸時代 人と現代関東人とのほぼ中間にあつて、白金頭骨より有意に大きい。

鼻根部执よび眼窩 :

鼻根部計測值の時代別資料との比較は別に第 5 表に示す通りである。ここでは現代人の資 料として、慈恵医大解剖学教室所蔵の現代関東地方人頭骨のうち、大正・昭和年代に出生し た個体を選び出し、その群について計測した結果（鈴木）を挙げてある。

第 5 表に見られるように、前眼窩間幅は室町時代以後減少している。白金頭骨の值は江戸 
第 5 表 鼻根部計測值の比較 $(\mathrm{mm})$

記号は第 $3 、 4$ 表に同じ。

\begin{tabular}{|c|c|c|c|c|c|c|c|c|c|c|}
\hline & & & $\begin{array}{l}\text { 銭倉洔代 } \\
\text { (鈴木他) }\end{array}$ & $\begin{array}{l}\text { 室町時代 } \\
\text { (鈴木䞏) }\end{array}$ & $\begin{array}{l}\text { 江戸時代 } \\
\text { (鈴木㤔) }\end{array}$ & & 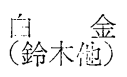 & & $\begin{array}{c}\text { 大正・昭和 } \\
\text { (鈴) } \\
\text { 木) }\end{array}$ & $\begin{array}{l}\text { 西荫日本 } \\
\text { (原 } \text { 田) }\end{array}$ \\
\hline \multirow{3}{*}{50} & \multirow{3}{*}{ 前眼篦間愊 } & $N$ & 108 & 51 & 119 & & 188 & & 63 & 108 \\
\hline & & $\bar{x}$ & 19.1 & 19.2 & 18.6 & $>$ & 18.0 & $>$ & 17.2 & 17.4 \\
\hline & & $u$ & 2.29 & 2.42 & 2.05 & & 2.14 & & 1.87 & 2.18 \\
\hline \multirow{3}{*}{$\mathrm{F}$} & & $N$ & 99 & 48 & 108 & & 183 & & 63 & \\
\hline & 前眼窩間横弧長 & $\bar{x}$ & 21.4 & 21.1 & 21.2 & & 20.7 & & 20.5 & \\
\hline & & $u$ & 2.65 & 2.63 & 2.17 & & 2.31 & & 2.10 & \\
\hline & & $N$ & 96 & 47 & 108 & & 183 & & 63 & \\
\hline & $\mathrm{F}$ 䝿根隆起示数 & $\bar{x}$ & 89.0 & 89.7 & 87.4 & & 86.7 & $>$ & 84.4 & \\
\hline & & $u$ & 4.72 & 4.87 & 4.68 & & 5.35 & & 4.94 & \\
\hline \multirow{3}{*}{ G } & & $N$ & 106 & 49 & 114 & & 183 & & 64 & \\
\hline & 前頭突起上幅 & $\bar{x}$ & 9.5 & 9.1 & 9.0 & & 8.8 & $(>)$ & 8.5 & \\
\hline & & $u$ & 1.39 & 1.18 & 1.22 & & 1.41 & & 1.41 & \\
\hline \multirow{3}{*}{57} & & $N$ & 108 & 52 & 128 & & 188 & & 64 & 108 \\
\hline & 鼾骨最小幅 & $\bar{x}$ & 8.0 & 7.8 & 7.6 & $>$ & 7.2 & & 7.3 & 7.1 \\
\hline & & $u$ & 2.29 & 2.02 & 1.76 & & 1.79 & & 1.45 & 2.09 \\
\hline
\end{tabular}

時代人と現代人との哃にあつて、現代人よりも有意に大きく、江戸時代人よりは有意に小 さい。また西南日本人の值は現代（大正・昭和）関東人に近く。白金頭骨との差は有意であ る。

これに対して前眼简間幅に対応する弧長（mf-mf，前眼窩間横弧長 F ) には著しい変化は 起つていない。従つて両者の比 $(50: \mathrm{F}$ 、鼻根隆起示数) は空町時代以後。現代に向つて減 少している。白金頭骨の值は江戸㭙代と現代の間にあるが。後者よりも前者に近く、現代と の差は有意である。

この示数は本来、鼻根の隆起を示すから、白金の明治維新の人々は江戸時代人よりやや隆 起の強い鼻根をもつが、現代人からみると遙かに低く、むしろ江戸封代人、室町㭙代人に近 い隆起をもつていたと思われる。

$\mathrm{mf}$ に括ける上顎骨前頭突起上幅は鎌倉時代以後次第に減少し、現代が最も狭い。白金頭 骨は江戸跀代人と現代人との中間にあるが、その差は著明ではない。

鼻骨最小幅は鎌倉侍代以後、現代に向つて減少しているぶ、白金頭骨は江戸時代人より有 意に小さく、現代人との差は明らかでない。

第 4 表に見られるよ5に、眼筒幅は鎌倉時代より江戸時代に至るまで变化がないが、現代 関東人ではこれらより小さくなつている。白金頭骨の值は江戸時代人ょり有意に小さく、現 代関東人よりも更に小さいが有意差はない。西南日本人の値はむしろ江戸時代人に近く、白 金頭骨よりも有意に大きい。

眼窩高は鎌倉時代人に括いては小さい值を示すが、室町時代以降現代人に至るまで变化な く、白金頭骨の值もこれらと同等である。西南日本人の值もまた例外でない。 
眼窩示数は鎌倉時代以降増加の傾向を示している。白金頭骨の值は江戸時代人より有意差 をもつて犬きく、現代関東人ょりもな扔幾分大さいが、その差は有意ではない。西南日本人 の值は現代関東人に近い。

骨性鼻 :

鼻幅は室町、江戸の両時代間に差はないが、他は時代と共に減少する。白金頭骨の值は江 戸時代人と現代関東人との中間にあつて、しかもその差は両方とも有意であるが、現代との 差の方が大きい。西南日本人の值は江戸時代人と白金頭骨との中間にあるが、その差は有意 でない。

鼻高は江戸時代に至るまで増加し、それ以後は逆に僅かに減少する傾向が見られる。白金 頭骨の值は江戸時代人と現代関東人との中間にあるが、その差はいずれも有意でなく、西南 日本人の值にも一致する。

鼻示数は鎌倉時代以降漸減の方向をたどる。白金頭骨の值は江戸時代人と現代関東人との 中間にあるが、いずれとの差も有意でない。しかし現代関東人との差の方がやや明らかであ る。西南日本人の值はこれに反して江戸時代人と同等である。

顔面角：

全側面角は時代と共に増加する。白金頭骨の值は江戸時代人と現代人との中間にあつて江 戸時代人の方にやや近く、現代関東人よりは有意に小さい。西南日本人の值は白金頭骨より もやや大さいが有意差はない。

鼻側面角は江戸時代人の值を頂点として、その後再び減少する傾向が見られる。白金頭骨 の値は江戸時代人と現代関東人との中間で、より現代に近いが、これらの両群との差はいず れも有意ではない。西南日本人の值は現代関東人と同等である。

歯槽側面角は全側面角と同様に時代と共に増加しているが、その変化は江戸時代以降に掠 いて著しい。白金頭骨の值は江戸時代人と現代関東人との中間にあつて、その差は両方とも 有意であるが特に現代関東人との差が大きく、江戸時代以前の各群と同じく過突顎 hyperprognath に属する。また西南日本人の值は現代関東人よりはかなり小さいが、同じく突顎 prognath 飞属し、白金頭骨より有意に大さい。

\section{総括物よび考察}

以上に主要な計測項目について述べたところを琶約すると、白金頭骨は多くの計測值から 見て関東地方の江戸時代人と現代人との中間にあるが、一部はそのどららかに近い。この関 係を項目別に分類すると次のようになる。

（1）江戸時代人に近く、現代人と差があるもの：

最大幅、横弧長、鼻示数、全側面角、鼻根の隆起。

(2) 両者の中間にあつて、そのいずれそも差があるもの：

鼻幅、歯槽側面角、前眼窩間幅。

（3）江戸時代人と差があり、現代人に近いもの：

最大長、長幅示数、長高示数、水平周、上顔幅、頓弓幅、上顔高、上顔示数、両眼䈑幅、 眼窝幅、眼窩示数、鼻骨最小幅。

(4) 両者のいずれとも有意差がないもの： 
頭骨 modulus、バジオン・ブレグマ高、幅高示数、正中矢状弧長、中顔幅、眼窩高、 鼻高、鼻側面角、前眼简間横弧長。

このことから、白金頭骨は多くの点で現代関東人により近いが、な招かなりの江戸壯代人 的形質を示していることが認められる。

もちろん白金頭骨は比較に用いた関東地方の時代別の資料とその出自を珙にするので、形 質の地方差を考慮するならば、関東地方人の侍代的変化の流れの中に位置せしめることには 疑問がある。しかし上に述べた話測值に関する限り、関東地方について見ることのできる鎌 倉時代より現代に至る日本人の封代的変化の過程の中で、白金頭骨もまた汀戸封代と現代と の中間に位する一つの時代相を強く現わしていると仮定してる、現在のところ少しも矛盾し ないように見える。

もしこの仮定が成立するならば、白金頭骨の形質を知ることによつて、江戸侍代から現代 にかけての変化の様相について、一つの具体的な示唆を得ることができる。すなわち、この 両㭙代の頭骨の形質間に見られる比較的著明な差異は、すべての变化が一様に進行した結果

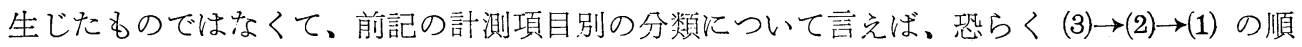
序で起つたものであると推定することが可能である。

此較に用いた原田（1954）の西南日本人に関する数值は、ある項目に拈いては白金頭骨の 值と近似するが、ある項目では江戸時代人や現代関東人に近く、またある項目ではこれらの いずれとも異つているものもあり、や〉特異な形質を示している。この原因の一つとして、 白金頭骨の場合には出自が比較的西日本飞偏つているとはい光、な拉日本全国に瓨つている のに反し、西南日本人では出自が限局されて怙り、そのため地方差の要因が強く表現されて いる可能性が考えられる。

また白金頭骨の形質を他の資料と比較する時に考虑せねばならないのは社会的な階層の問 題である。一般に社会階層を異にする群の間に形質の差が見られることは、古愤時代に叔け る高塚古墳と横穴古墳より由来する人骨の間に存在する差異の例でも知られるが、現代人に おいて子池田ら（1954、1955；九学会德合刘馬共同調查委員会 1954）の対馬自民の研究で士 族と平民との間に差が認められて扣り、まて未発表ではあるが、われわれの江戸時代に括け る武士階級の資料も同時代の庶民と形質の上で相違を示している。これらの差異を一言にし ていえば、武士は同時代の庶民よりも、むしろ後の時代と多くの類似点をもつており、いわ ばより進んだ形質を示すように思われる。白金墓地埋葬者の半数近くが士族出身者であるこ とを考劣ると、白金頭骨の示している形質が、同時代の日本人の真に平均的な形質よりも、 な打幾分現代日本人に近い位置にある可能性もある。このことは、前に述べたように白金頭 骨を発掘された墓区によつて 2 群に分けたた封、士族出身者の多い第 1 群（甲乙丙丁）と、 比較的に平民出身者の多い第 2 群（戊已）との間に幾つかの計測項目において差があるらし く、中でも頭骨最大幅、長幅示数、上顔示数、顔面角などで、いずれも第 1 群の方が大きく、 したがつて現代人に近いように見觉る事実からも、ある程度裏づけられるように思われる。

これらの諸点、すなわら日本人形質の侍代的変化に拈ける、地域的特殊性の開題特よび社 会階層の特殊性の問題は、将来更に他の資料の検討によつて明らかにさるべきものであると 考光る。 


\title{
文献
}

原田忠昭、 1954 : 西南日本人頭骨の人類学的研究。人類学研究、1、1 2。 池田次郎、蒲生正男、1954: 対馬の士族について。日本人類学会日本民族学協会連合大会第 7 回紀事。 池田次郎、蒲生正男、佐久聰太郎、1 1955 : 対馬士族—一社会階層之身体形質の問題。人類学輯報、12。 九学会連合対馬共同調査委員会、1954: 対馬の自然之文化、刘馬島民の形質人類学的研究。古今書院。 Martin, R., 1928 : Lehrbuch der Anthropologie, 2. Aufl.

森田 茂、1950: 関東日本人頭蓋骨の人類学的研究。袐患医大解剖学教室業績、3。

鈴木 尚、1954: 石器時代より現代に至る日本人鼻根部形態の時間的推移について (予報)。日本人類学 会日本民族学協会連合大会第 7 回紀事。

SUzUKI, H., 1956: Changes in the skull features of the Japanese people from ancient to modern times. Selected Papers of the Fifth International Congress of Anthropological and Ethnological Sciences. Philadelphia, 1956.

鈴木 尚、1957：日本人形質の時代的変化。ダーウィン進化論百年記念論集。

鈴木 尚、1959：鎌倉時代の日本人。日本の医学の 1959 年（第15回日本医学会総会学術集会記録、1)、 pp. $175-176$ 。

鈴木 尚、林都志夫、田辺義一、佐倉 朔、1956 : 鎌倉材木座発見の中世遺跡之その人骨、XI 頭婴の 形質。岩波書店。

鈴木 尚、佐倉 鄯、江原昭善、1957 : 深川雲光院出土の江戸時代人頭骨について。日本人類学会日本 民族学協会連合大会第11回紀事。

鈴木 尚、佐倉 朔、保志 宏、1958: 東京丸の内附近より発掘された中世末期の日本人頭骨につい て。日本人類学会日本民族学協会連合大会第12回紀事。

鈴木 尚、田辺義一（東京大学理学部人類学教室）佐倉 朔 (東京医科歯科大学総合法医学研究施設)

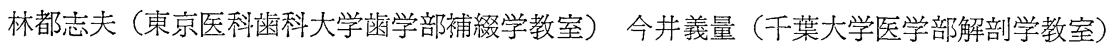

\section{Craniometry of the Japanese Skulls of the Final Edo Era}

\author{
Hisashi Suzuki, ${ }^{1)}$ Hajime Sakura, ${ }^{2}$ Toshio Hayashi, ${ }^{3)}$ \\ Girchi TANABe ${ }^{4)}$ and Yoshikazu Imai ${ }^{5)}$
}

The changes in the physique of the Japanese through the historic ages have been traced since about ten years ago in the researches by SuzukI, one of the present authors, and others. So far as the morphological characteristics of the head and face are concerned the change seems to be more rapid in the period from Edo era (17th-19th c.) to the present time than in the earlier periods in the history of Japan. Therefore, it is certainly one of our major interests to know the physical characteristics of the people who lived in the latter half of 19th century, which is an intermediate epoch between the two eras and is the dawn of modern Japan.

Fortunately, the remains of the navy tomb, situated at Shirogane in Tokyo, in which 592 sailors and officers of the early period of the Japanese navy had been buried, were re-buried several years ago, and 191 skulls of them became available for our investigation.

According to the document of the tomb, most of the buried persons were born in 1841 70 and died in 1873 90. Many of the officers and warrant officers were derived 
from samurai familyi n the feudal age, while a majority of the sailors were common people. As these two groups were buried in different parts of the tomb, the skulls could be separated for examination into three subgroups, i. e., (1) officers and warrant officers, (2) sailors, and (3) unknown classes.

The results of the craniometry of Shirogane people were compared with those of the peoples of various historic ages (Suzuki et al.) and contemporary Japanese from Tokyo-Yokohama area. In many of the characteristics of the skull, Shiroagne people show an intermediate form between the people of Edo era and contemporary Japanese, and in some other characteristics they are nearer to either the former or the latter. The details are as follows:

(1) The group of characteristics in which Shirogane people are nearer to Edo people and show significant differences from contemporary Japanese are the maximum head breadth, transversal arc length, nasal form, profile angle and prominence of the nasal root.

(2) The group of characteristics in which Shirogane people are intermediate and show significant differences both from Edo people and contemporary Japanese are the nasal breadth, inter-orbital breadth and alveolar profile angle.

(3) The group of characteristics in which Shirogane people show marked differences from Edo people and are rather near to contemporary Japanese are the maximum head length, length-breadth index of the head, length-height index of the head, horizontal circumference of the head, facial breadth and height, facial form, bi-orbital breadth and orbital form.

(4) Shirogane people show no significant differences either from Edo people or from contemporary Japanese in the module of the head, basi-bregmatic height, medio-sagittal arc length, middle facial breadth, orbital and nasal height, etc.

Accordingly, it is probable that the changes in characteristics have not occurred simultaneously in all of them but in the order of the groups of characteristics (3), (2) and (1).

The fact that there are some differences in measurement values between the officers and the sailors, buried in different parts of the tomb, is probably due to the difference between two social classes in the feudal age, the samurai and the common people. The homologous phenomenon has already been found in the study of Tsushima islanders (IKEDA et al.), in which the samurais seem to have more progressive characteristics than the common people.

\section{1),4) Department of Anthropology, Faculty of Science,} Tokyo University.

2) General Institute of Legal Medicine. Tokyo Medical \& Dental University.

3) Department of Prosthetic Dentistry, Tokyo Medical \&. Dental University.

5) Department of Anatomy, Chiba University School of Medicine. 